\title{
Dysregulated Expression of Glycolipids in Tumor Cells: From Negative Modulator of Anti-tumor Immunity to Promising Targets for Developing Therapeutic Agents
}

\author{
Jose Luis Daniotti ${ }^{1 *}$, Ricardo D. Lardone ${ }^{2}$ and Aldo A. Vilcaes ${ }^{1}$ \\ ${ }^{1}$ Centro de Investigaciones en Química Biológica de Córdoba (CIQUIBIC, UNC-CONICET), Departamento de Química \\ Biológica, Facultad de Ciencias Químicas, Universidad Nacional de Córdoba, Córdoba, Argentina, ${ }^{2}$ Dirks/Dougherty \\ Laboratory for Cancer Research, Department of Translational Immunology, John Wayne Cancer Institute at Providence Saint \\ John's Health Center, Santa Monica, CA, USA
}

OPEN ACCESS

Edited by:

Leonardo Freire-de-Lima, Federal University of Rio de Janeiro,

Brazil

Reviewed by:

Stephan Von Gunten,

University of Bern, Switzerland

Eduardo J. Salustiano,

Federal University of Rio de Janeiro,

Brazil

*Correspondence:

Jose Luis Daniotti

daniotti@fcq.unc.edu.ar

Specialty section:

This article was submitted to

Molecular and Cellular Oncology,

a section of the journal

Frontiers in Oncology

Received: 20 November 2015

Accepted: 14 December 2015

Published: 07 January 2016

Citation:

Daniotti JL, Lardone RD and

Vilcaes AA (2016) Dysregulated Expression of Glycolipids in Tumor Cells: From Negative Modulator of Anti-tumor Immunity to Promising Targets for Developing Therapeutic

Agents.

Front. Oncol. 5:300.

doi: 10.3389/fonc.2015.00300
Glycolipids are complex molecules consisting of a ceramide lipid moiety linked to a glycan chain of variable length and structure. Among these are found the gangliosides, which are sialylated glycolipids ubiquitously distributed on the outer layer of vertebrate plasma membranes. Changes in the expression of certain species of gangliosides have been described to occur during cell proliferation, differentiation, and ontogenesis. However, the aberrant and elevated expression of gangliosides has been also observed in different types of cancer cells, thereby promoting tumor survival. Moreover, gangliosides are actively released from the membrane of tumor cells, having a strong impact on impairing anti-tumor immunity. Beyond the undesirable effects of gangliosides in cancer cells, a substantial number of cancer immunotherapies have been developed in recent years that have used gangliosides as the main target. This has resulted in successful immune cell- or antibody-responses against glycolipids, with promising results having been obtained in clinical trials. In this review, we provide a general overview on the metabolism of glycolipids, both in normal and tumor cells, as well as examining glycolipid-mediated immune modulation and the main successes achieved in immunotherapies using gangliosides as molecular targets.

Keywords: glycolipids, gangliosides, cancer, antibodies, immunotherapy, immunotoxin

\section{INTRODUCTION}

Differentially expressed tumor-associated carbohydrates represent a general phenomenon observed in many types of cancer cells. Carbohydrates covalently attached to glycolipids are not the exception. Neosynthesized glycolipids observed in oncogenic processes show antigen specificity and, therefore, they are attractive candidates for the design of cancer vaccines. The poor immunogenicity, low-affinity immunoglobulin responses, and immunotolerance associated with glycolipids have been overcome with the advent of new technologies and combinatorial immunotherapies. Nevertheless, these remarkable advances are being counteracted for striking effects on anti-tumor immunity exerted by 
particular molecular species of tumor-secreted glycolipids and, hence, strategies involving the use of glycolipid synthesis inhibitors are being considered.

\section{GLYCOLIPID METABOLISM AND FUNCTIONS}

Glycolipids are molecules containing one or more carbohydrate residues linked to a hydrophobic lipid moiety via a $\beta$-glycosidic linkage. Those containing either a sphingoid or a ceramide as the hydrophobic lipid moiety are referred to as glycosphingolipids (GSLs). A particular subclass of glycolipids is the gangliosides, which are sialylated GSLs mainly expressed in the outer layer of the plasma membrane of essentially all vertebrate cells. The biosynthesis of gangliosides starts with the synthesis of ceramide at the cytoplasmic leaflet of the endoplasmic reticulum membrane, where the pyridoxal 5'-phosphate-dependent serine palmitoyltransferase catalyzes the condensation of palmitoyl- or stearoylCoenzyme A with L-serine to give 3-ketosphinganine, which is reduced to D-erythro-sphinganine by 3 -ketosphinganine reductase in a NADPH-dependent reaction. D-erythro-sphinganine is further acylated to generate different dihydroceramides by a family of ceramide synthases. Next, dihydroceramide is unsaturated at the 4,5 position by DES1 desaturase to make ceramide. The de novo synthesized ceramide is then transported from the endoplasmic reticulum to the trans Golgi, at least in part in a protein-dependent manner by the transport protein CERamide Transport (CERT), where it is catalytically converted to glucosylceramide (GlcCer) by the action of UDP-Glc:ceramide glucosyltransferase. Most GlcCer may subsequently be transported by the four-phosphate adaptor protein 2 (a glycolipid-transport protein carrying a PI4P-binding domain) either to the endoplasmic reticulum or to distal Golgi compartments, where it translocates to the lumen. $\beta 4 \mathrm{GalT}$-VI converts GlcCer to lactosylceramide (LacCer) and further carbohydrate residues, including negatively charged sialic acid, are transferred in a stepwise manner to the growing glycan chains (Figure 1A). Sialylated derivatives from LacCer are produced by the action of ST3Gal-V, ST8Sia-I, and ST8Sia-I/ST8Sia-V, which specifically catalyze the formation of the gangliosides GM3, GD3, and GT3, respectively. LacCer, GM3, GD3, and GT3 serve as precursors for more complex gangliosides of the 0 -, a-, b-, or c-series by sequential glycosylations catalyzed by $\beta 4$ GalNAcT-I, $\beta 3$ GalT-IV, ST3Gal-II, and ST8Sia-V. After synthesis at the Golgi complex, gangliosides are mainly delivered by vesicular transport to the plasma membrane, where they can undergo endocytosis. In addition to the bulk ganglioside synthesis at the Golgi complex level, ganglioside formation by plasma membrane-associated glycosyltransferases has been recently also reported (1-4). See Ref. (5-9) for an extensive review on ganglioside biosynthesis and molecular transport pathways.

The catabolism of gangliosides takes place mainly at the lysosomes, although degradation of gangliosides can also occur at the cell surface by the action of the sialidase Neu3, $\beta$-galactosidase, and $\beta$-glucosidase (10-14). At the lysosomal level, gangliosides are sequentially degraded by the action of glycosidases that sequentially cleave off the monosaccharide units from the non-reducing end of the ganglioside glycan chains. Adequate lysosomal ganglioside catabolism requires the presence of an appropriate $\mathrm{pH}$, suitable glycosidases, and lipid-transfer proteins for the degradation of simple gangliosides, which extracts the membrane-bound glycolipids and presents them to the soluble acid hydrolase [see Ref. (15-17) for an extensive review on pathways of ganglioside catabolism].

Ganglioside expression changes with cell growth, differentiation, viral transformation, oncogenesis, and ontogenesis (18-21). Gangliosides, originally identified as structural components of biomembranes, were later acknowledged as key lipids implicated in a range of cellular processes. Thus, gangliosides are involved in many physiological processes, including growth, differentiation, migration, and apoptosis through modulating both cell signaling processes and cell-to-cell and cell-to-matrix interactions (22-28). Moreover, gangliosides have been associated with a wide range of pathological processes, being receptors for viruses, toxins, and autoantibodies associated with clinically identifiable acute and chronic neuropathy syndromes. In addition, inherited defects in the biosynthesis or degradation of gangliosides have also been described, which causes a group of diseases mainly associated with severe neurodegenerative disorders (29-34).

Although the plasma membrane is the major cellular reservoir of gangliosides, it is not the final destination for these molecules. Thus, in addition to cell internalization, sorting to lysosomes or plasma membrane recycling, gangliosides can be actively shed from the membrane of one cell and taken up by other cells by insertion of their lipid anchors into the cell membrane. Although the shedding and uptake of gangliosides are a physiological process observed in many types of cells, increased levels have been detected in various tumors, such as melanomas, renal carcinoma, astrocytomas, and glioblastomas (35-39). Many reports have described that shedding of gangliosides helps to suppress the immune response, probably by modifying membrane composition of immune cells and, hence, inhibiting their function and allowing tumor escape. This topic is further reviewed below.

\section{GLYCOLIPID-MEDIATED IMMUNE MODULATION}

Tumors have a complex interrelation with the immune system. The immunoediting paradigm (40) describes how pressure exerted by immune cells recognizing and eliminating tumor cells results in the selection for poorly recognized malignant cells. Tumors can further disrupt this apparent equilibrium by inducing an immunosuppressive environment that allows tumor cells escape (41). Gangliosides shed from tumors and reaching immune cells have potential to contribute mechanisms suppressing the immune system. Innate immunity cell populations, such as monocytes, macrophages, and dendritic cells (DC), kill tumor cells directly, release inflammatory mediators to recruit and differentiate adaptive immune cells, and present tumor antigens to T cells (42-44). Natural killer (NK) cells kill tumors directly depending on the balance between inhibitory and activating signals from invariant receptors (45). Natural killer T (NKT) cells can target lipid and glycolipid antigens in the context of 
A

0-series

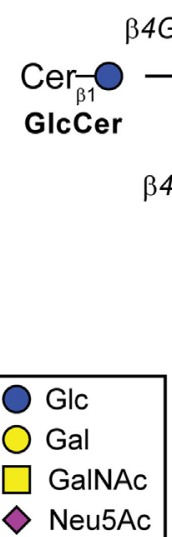

34GalT-VI

$\longrightarrow \mathrm{Cer}_{\beta 1}^{-}-\mathrm{O}$

34GaINACT-I

LacCer

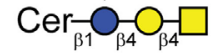

B3GalT-IV
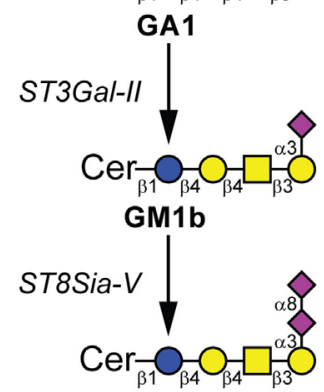

GD1c a-series

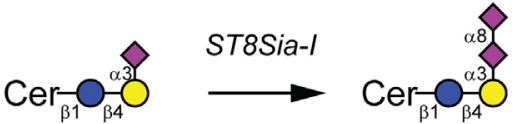

ST8Sia-I

ST8Sia- $V$

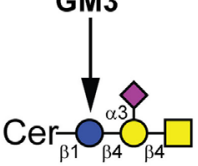

GM2
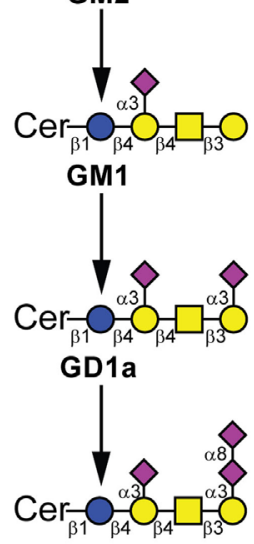

GT1a
GD3
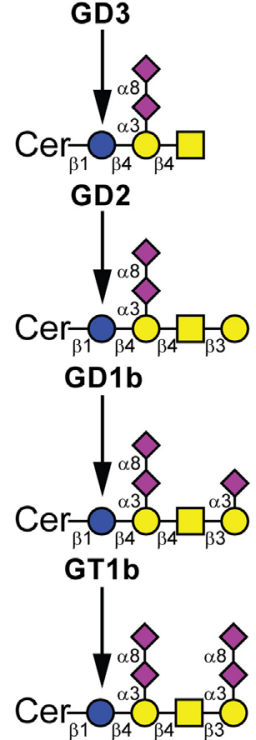

GQ1b c-series

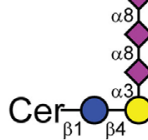

GT3
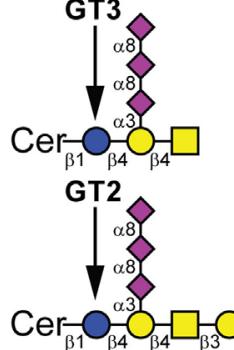

GT1C
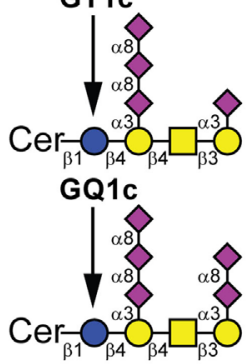

GP1C

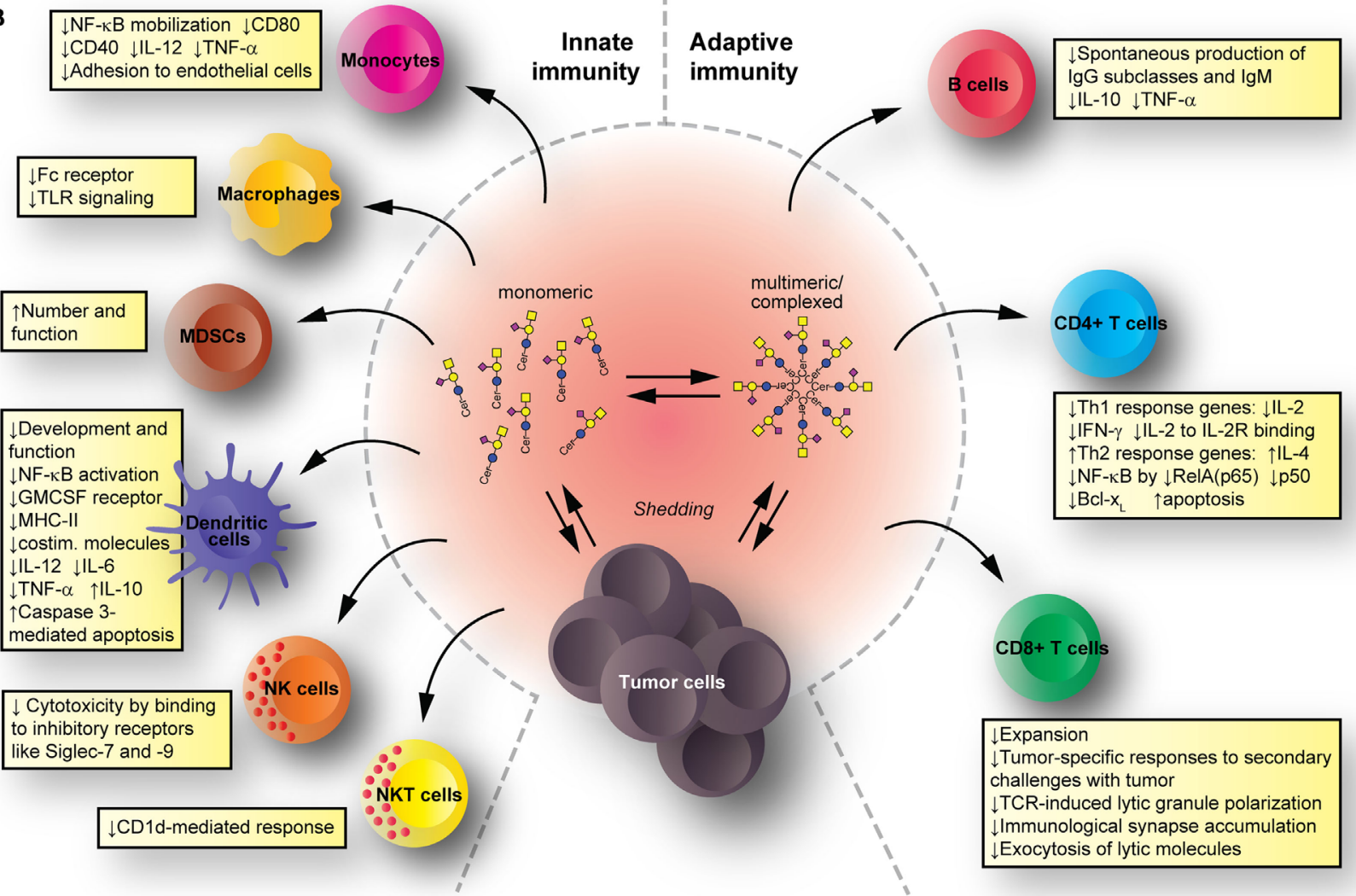

FIGURE 1 | Synthesis and immunomodulatory effect of gangliosides. 


\section{FIGURE 1 | Continued}

(A) Pathway for ganglioside biosynthesis representing the stepwise addition of monosaccharides to ceramide, and the resulting structures. $\beta 4 \mathrm{GalT-VI}$, UDPGal:glucosylceramide galactosyltransferase; ST3Gal-V, CMP-NeuAc:lactosylceramide sialyltransferase; ST8Sia-I, CMP-NeuAc:GM3 sialyltransferase, and CMP-NeuAc:GD3 sialyltransferase; $\beta 4$ GalNAcT-I, UDP-GalNAc:lactosylceramide/GM3/GD3/GT3 N-acetylgalactosaminyl transferase; $\beta 3 G a l T-I V$, UDP-Gal:GA2/ GM2/GD2/GT2 galactosyltransferase; ST3Gal-II, CMP-NeuAc:GA1/GM1/GD1b/GT1c sialyltransferase; ST8Sia-V, CMP-NeuAc:GM1b/GD1a/GT1b/GQ1c sialyltransferase, and CMP-NeuAc:GD3 sialyltransferase. Cer, ceramide; Glc, glucose; Gal, galactose; GalNAc, N-acetylgalactosamine; Neu5Ac, N-acetylneuraminic acid (sialic acid). (B) Mechanisms for glycolipid-mediated immune modulation. Tumors shed gangliosides to extracellular milieu, where they are in dynamic equilibrium between monomeric, multimeric, and larger, hetero-complexed forms. From these various states, they have the potential to transfer to different immune cells, modify their membrane composition, and induce modifications that modulate innate and adaptive immunity. The summarized changes can thus favor tumor escape.

(MHC-I resembling) CD1 molecules and mediate anti-tumor effects (46). Among the adaptive immunity cell populations, we find B cells (producing anti-tumor antibodies targeting cancer cells for killing by effector cells, and presenting antigen to T cells), as well as CD4+ $\mathrm{T}$ cells (helping with antibody production and cell-mediated immune responses) and CD8+ T cells [effector cells for tumor killing (47)]. The immunomodulatory effects by gangliosides take place to the level of both, the innate and the adaptive immunity (Figure 1B).

\section{Mechanisms Suppressing Innate Immunity}

Human brain gangliosides impede up-regulation of the costimulatory molecule CD80 (without affecting expression of I-CAM-1, LFA-3, HLA-DR, and CD86) on monocytes (48). Similarly, exposing monocytes to GD1a also inhibits CD80 up-regulation, decreases CD40 levels, and reduces LPS-stimulated interleukin (IL)-12 and TNF- $\alpha$ (49) by impeding NF- $\kappa B$ mobilization (50). In addition, pre-incubation of monocytes with certain gangliosides can impair Fc receptor expression (by GM2 and GM3), IL-1 production (by GM1 and GD3) (51), and TLR signaling (52). Moreover, GM3 reduces the monocyte adhesion to endothelial cells (53). Importantly, tumor-derived gangliosides can increase number and function of myeloid-derived suppressor cells to favor immune escape (54).

Gangliosides, such as GM2 (55), GD1a (56), GM3, and GD3 (57), can affect in vitro development and function of monocytederived DC. Expression of MHC class II, costimulatory molecules, and CD116 (GM-CSF receptor) on DC is reduced by GM2. Endocytic, chemotactic, and T cell proliferation-inducing activities are also targeted. Meanwhile, GD1a mediates a poor DC response to activating conditions by reducing costimulatory molecules, IL-12, TNF- $\alpha$, and IL- 6 production, and increasing IL-10 release $(49,56)$, presumably through NF- $\kappa$ B activation disruption. This impaired response of activated DC is also observed with GM3 and GD3 (57), which also induce caspase 3-mediated apoptosis (57-59). NK cell cytotoxicity against tumor cells is reduced by tumor gangliosides binding to inhibitory receptors such as Siglec-7 and -9 (60-62). Finally, gangliosides can also interfere with NKT cells activation, such as GD3 in ovarian cancer (63) and GM2 in lymphoma (64), often acting as inhibitory ligands for the CD1d-mediated NKT cell response.

\section{Mechanisms Suppressing Adaptive Immunity}

GM2 and GM3 gangliosides added in vitro to B cells inhibit spontaneous production of IgG subclasses and IgM, with no effect on IgA subclasses (65). At least for GM2, the mechanism involves reduction of endogenous IL-10 and TNF- $\alpha$ production (66), while the presence of TNF- $\alpha$ can counteract these inhibitions. In addition, certain complex gangliosides can affect IL- 6 and IL-10 production on CD4+ T cells (GD1b) and monocytes (GT1b) $(67,68)$, also leading to further reduced IgG, IgM, and IgA antibody production in co-cultures with B cells. Remarkably, GQ1b and GD1a can abrogate the effects of GD1b and GT1b to enhance Ig production by human peripheral blood mononuclear cells $(69,70)$. It is noteworthy to mention that no effects have been described for gangliosides on antigen presentation by B cells.

Regarding T cells, gangliosides can have effects at both, central (71) and peripheral (72) T cell compartments. The induction of cytolytic anti-tumor immunity relies on type- $1 \mathrm{~T}$ cell responses [conducted by interferon (IFN)- $\boldsymbol{\gamma}$ - and IL-2-producing T cells (73)], as opposed to type- $2 \mathrm{~T}$ cell responses (defined by $\mathrm{T}$ cells producing IL-4, IL-6, and IL-10) leading to cytolytic activity suppression (74). Indeed, cancer patients produce increased type- 2 cytokines (75). Several genes participate in T cell development, maturation, and proliferation, under transcriptional control of Rel/NF- $\kappa B(76)$. Renal cell carcinoma (RCC)-derived gangliosides reduce IL-2 and IFN- $\gamma$ expression (77) and increase apoptosis in $\mathrm{T}$ cells through NF- $\kappa \mathrm{B}$ inhibition by reducing RelA(p65), p50, and antiapoptotic protein Bcl- $\mathrm{x}_{\mathrm{L}}$ (78). Tumor- or brain-derived gangliosides present during in vitro activation-induced settings (e.g., with anti-CD3 antibody) also associate with type-2 response shifts in CD4+ and CD8+ T cell populations by decreasing IFN- $\gamma$ and often elevating IL-4 (79-81), along with increased apoptosis. Interestingly, in vivo findings show more apoptotic T cells in RCC patients having GM2 in their membranes but with negligible mRNA expression levels for GM2 synthase (82). This ectopic presence of GM2 could derive from the tumor and participate in apoptosis mediated by diverse mechanisms (82-86). Antigenspecific $\mathrm{T}$ cell activation is also interfered by the presence of gangliosides. These effects are mediated by IL-2 transcription blockade and phosphorylation inhibition of retinoblastoma protein in activated human $\mathrm{T}$ cells (81). Moreover, ganglioside mixtures can inhibit proliferation of IL-2-dependent $\mathrm{T}$ cell lines by a competitive inhibition for IL-2 binding to IL-2R, mediated by direct binding of gangliosides to a lectin-like site on IL-2 (87).

In vivo mice models indicate that cytotoxic $\mathrm{CD} 8+\mathrm{T}$ cell populations are also affected by gangliosides exposure, in terms of expansion and tumor-specific responses to secondary challenges with tumor cells (88). In addition, gangliosides prevent TCR-induced lytic granule polarization, immunological synapse 
accumulation, and exocytosis, without interfering on lytic molecule expression or target cell recognition (89).

Despite all these detrimental effects, the bright side of ganglioside dysregulation in tumors is the opportunity to aim them as molecular targets. Next section presents current promising immunotherapy strategies based on this principle.

\section{IMMUNOTHERAPIES USING GANGLIOSIDES AS MOLECULAR TARGETS}

Among the reported changes on lipid composition of tumor cell membranes, the remarkable modifications on the sialic acidcontaining glycolipids during neoplastic transformations have received special attention. This spectrum also includes molecules such as lacto- and neolacto-series glycolipids and globosides (GSLs containing acetylated amino sugars and simple hexoses). Tumors, such as melanoma, small-cell lung cancer (SCLC), sarcoma, and neuroblastoma, express gangliosides GD3, GM2, and GD2 in higher levels than corresponding normal tissue (90-94). Moreover, ganglioside derivatives, including $N$-glycolyl GM3 (NeuGcGM3) and fucosyl-GM1, are also increased (94-97). Therefore, a substantial number of cancer immunotherapies have been using sialylated glycolipids as major targets. However, no glycolipid-containing cancer vaccines have produced substantial clinical improvements. Nevertheless, several reviews have recently covered in depth and from different perspectives a renewed interest in therapeutic applications of glycoconjugates. Due to the stronger support based on the recent development of new tools and techniques, along with advances in the glycobiology field and potential combination with other therapeutic approaches, the authors share a common denominator: the re-emergence of gangliosides as promising targets for developing cancer therapeutic agents $(18,41,98-102)$. An example is GD3, highly expressed in tumor cells ( $>80 \%$ of melanomas) (90). Investigations focusing on this ganglioside as principal target were made in passive (103) and active (104) immunotherapy of melanoma cancer, with modest results (105). However, a recent strategy is evaluating a GD3-specific chimeric antigen receptor (CAR) to redirect T cell specificity to GD3 expressed on tumor cells surface (90) (Table 1). Recently, GD3 has been proposed as a suitable immunotherapy target for tumors developed in lymphangioleiomyomatosis (106). In this sense, the mouse monoclonal R24 antibody (IgG3) against ganglioside GD3 is a validated tumor targeting agent (107). Our laboratory demonstrated that the R24 antibody, after binding to GD3 at the cell surface, is rapidly internalized and accumulated in endosomal structures (108). We took advantage of this internalization feature for selectively delivering the toxin saporin (a ribosome-inactivating protein) to GD3-expressing human (SK-Mel-28) and mouse (B16) melanoma cells (109). This represented the first proof-of-concept of an original strategy in which a glycolipid emerges as a novel and attractive class of cell surface molecule for targeted drug delivery. Recently, this experimental strategy was also used for selective ablation of cell lines expressing 9-O-acetyl GD3 (110). Thus, ganglioside GD3 re-emerges as an attractive cell surface molecule for targeted delivery of cytotoxic agents such as saporin or, eventually, other drugs such as paclitaxel (Taxol) and doxorubicin $(111,112)$.

One of the strategies to generate an effective immune response against tumor-associated carbohydrate antigens (TACAs) involves the use of anti-idiotype antibodies as antigen surrogates. Although several investigations support the role of GM3 in suppression of cancer development and progression (99), overexpression of NeuGcGM3 has received special attention because it is minimally expressed on most normal human tissues. In the 1990s, it was described an anti-idiotypic murine monoclonal antibody (1E10) that reacts with a monoclonal IgM antibody (P3) binding to $N$-glycolyl-containing gangliosides. 1E10, commercially named racotumomab, mimics NeuGcGM3 ganglioside to induce a strong anti-metastatic effect in tumorbearing mice (126). Racotumomab is being evaluated for a wide range of NeuGcGM3-expressing tumors such as melanoma, breast cancer, non-SCLC, and several pediatric tumors of neuroectodermal origin (113, 127-133). A Phase II/III multicenter double-blind clinical trial evaluated racotumomab vaccine effects in the overall survival in advanced non-SCLC patients (134). This study showed a significant clinical benefit for patients treated with the anti-idiotype vaccine. On the basis of these promising results, racotumomab was launched in 2013 in Cuba and Argentina as an intradermal injection for treating patients with advanced stage non-SCLC (113). It is worth mentioning that naturally occurring antibodies against TACAs have been detected in both, cancer patients and healthy donors $(135,136)$. In addition, TACAspecific antibodies were screened in pooled sera of thousands of healthy donors. Notably, a structure-immunogenicity relationship was observed (137). Thus, idiotypic vaccination could be an optimal way to activate immune response cascades involving the natural responses against these antigens. Recent results suggest the existence of antibodies against NeuGcGM3 with anti-tumor immune surveillance functions, reinforcing the importance of $\mathrm{N}$-glycolylated gangliosides as anti-tumor targets $(138,139)$.

Other TACAs are GD2, ranking 12 out of 75 potential targets for cancer therapy by National Cancer Institute pilot program for the prioritization of the most important cancer antigens (140). Combination of anti-GD2 antibody (ch14.18) with IL-2 and GM-CSF significantly improves survival for high-risk neuroblastoma patients $(141,142)$. The aforementioned study reflects the need to combine cancer immunotherapeutic treatments with other interventions. In this sense, safe transfer of CAR-based immunotherapy into clinical practice represents a potential alternative to conventional treatment options for cancer patients. Similar to GD3, CAR technology associated with GD2 has already shown significant anti-tumor activity in neuroblastoma patients $(143,144)$.

As mentioned in the previous section, tumor cells shed gangliosides and populate their microenvironment with these and other biologically active GSLs. Recently, strong evidences indicate that gangliosides synthesized and released by tumor cells have critical proangiogenic activity in vivo, which is associated with enhanced tumor growth (145). These findings indicate that inhibition of human tumor ganglioside synthesis could be a novel therapeutic target for human cancer. At this respect, $\mathrm{N}$-butyldeoxynojirimycin, an imino-sugar 
TABLE 1 | Current and promising immunotherapeutic strategies involving tumor-associated gangliosides.

\begin{tabular}{|c|c|c|c|c|c|c|}
\hline Ganglioside & $\begin{array}{l}\text { Type of } \\
\text { treatment }\end{array}$ & Description & $\begin{array}{l}\text { Type of } \\
\text { acquired } \\
\text { immunity }\end{array}$ & $\begin{array}{l}\text { Phase of } \\
\text { clinical } \\
\text { research }\end{array}$ & $\begin{array}{l}\text { Type of human } \\
\text { tumor }\end{array}$ & Reference \\
\hline N-glycolyl-GM3 & $\begin{array}{l}\text { Anti-idiotype Ab } \\
\text { (racotumomab) }\end{array}$ & $\begin{array}{l}\text { Murine gamma-type anti-idiotype monoclonal antibody } \\
\text { that specifically induces an antibody response to } \\
\text { Neu5Gc-containing gangliosides, sulfatides, and other } \\
\text { antigens expressed in tumors }\end{array}$ & Active & Phase III trial & $\begin{array}{l}\text { Non-small-cell } \\
\text { lung cancer }\end{array}$ & $(102,113,114)$ \\
\hline \multirow[t]{5}{*}{ GD2 } & $\begin{array}{l}\text { A chimeric } \\
\text { Hu-murine } \\
\text { antibody }\end{array}$ & $\begin{array}{l}\text { Anti-GD2 Ab Ch14.18 + GM-CSF + IL-2 + isotretinoin } \\
\text { Anti-GD2 Ab (hu14.18K322A). Humanized anti-GD2 } \\
\text { Ab with a single point mutation (K322A) that reduces } \\
\text { complement-dependent lysis }\end{array}$ & Passive & $\begin{array}{l}\text { Phase I trial } \\
\text { Phase I trial }\end{array}$ & $\begin{array}{l}\text { High-risk } \\
\text { neuroblastoma } \\
\text { Refractory } \\
\text { or recurrent } \\
\text { neuroblastoma }\end{array}$ & $(116)$ \\
\hline & $\begin{array}{l}\text { Immunocitokine } \\
\text { chimeric hu14.18 } \\
\text { Ab-IL2 }\end{array}$ & $\begin{array}{l}\text { Hu14.18-IL2 fusion protein consists of interleukin-2 } \\
\text { molecularly linked to a humanized monoclonal antibody } \\
\text { that recognizes the GD2 }\end{array}$ & & Phase II trial & $\begin{array}{l}\text { Relapsed/ } \\
\text { refractory } \\
\text { neuroblastoma } \\
\text { metastatic } \\
\text { melanoma }\end{array}$ & $(118,119)$ \\
\hline & CAR & $\begin{array}{l}\text { Natural killer-92 cells stably express a GD2-specific } \\
\text { CAR, which carries a cell-binding domain derived from } \\
\text { antibody ch14.18 } \\
\text { Cell line: Hu neuroblastoma }\end{array}$ & & Preclinical & - & $(120)$ \\
\hline & $\begin{array}{l}\text { Anti-idiotype Ab } \\
\text { (gangliomab) }\end{array}$ & $\begin{array}{l}\text { Immunization of Balb/c mice with 14G2a (murine } \\
\text { monoclonal antibody to GD2), and splenocytes were } \\
\text { harvested to generate hybridoma cells. Clones were } \\
\text { screened for mouse antibody binding to hu14.18 } \\
\text { Cell line: Hu neuroblastoma }\end{array}$ & Active & Preclinical & - & $(121)$ \\
\hline & Inhibitor & $\begin{array}{l}\text { Triptolide, a small molecule inhibitor, inhibits ST8-Sial } \\
\text { expression, GD2 biosynthesis, and cancer stem cells- } \\
\text { associated properties } \\
\text { Cell line: Hu breast cancer/human tissue }\end{array}$ & - & Preclinical & - & $(122-124)$ \\
\hline \multirow[t]{3}{*}{ GD3 } & $\begin{array}{l}\text { Targeted delivery } \\
\text { of cytotoxic } \\
\text { agents }\end{array}$ & $\begin{array}{l}\text { Secondary antibody coupled to Zap bounded to the } \\
\text { mouse antibody to GD3 R24 } \\
\text { Cell line: Hu and mouse melanoma }\end{array}$ & - & Preclinical & - & (109) \\
\hline & $\begin{array}{l}\text { Targeted delivery } \\
\text { of cytotoxic } \\
\text { agents }\end{array}$ & $\begin{array}{l}\text { Secondary antibody coupled to Zap bounded to NG2 } \\
\text { and a GD3A9-O-acetyl GD3 antibodies } \\
\text { Cell line: Hu glioblastoma multiforme }\end{array}$ & - & & & (110) \\
\hline & CAR & $\begin{array}{l}\text { Anti-GD3 tandem chimeric sFv-CD28/T-cell receptor } \\
\text { zeta designer T cells. Second generation } \\
\text { Cell line: human melanoma. Model animal: BALB/c } \\
\text { nude mice }\end{array}$ & Passive & & & $(90)$ \\
\hline GM2 & $\begin{array}{l}\text { Synthetic } \\
\text { carbohydrate- } \\
\text { based vaccines }\end{array}$ & $\begin{array}{l}\text { Unimolecular pentavalent construct KLH conjugate } \\
\text { (UPC-KLH, 2). Five prostate and breast cancer- } \\
\text { associated carbohydrate antigens, globo-H, GM2, STn, } \\
\text { TF, and Tn conjugated to the carrier protein KLH } \\
\text { Model animal: mice (C57BL/6J) }\end{array}$ & Active & Preclinical & - & $(125)$ \\
\hline
\end{tabular}

Ab, antibody; NG2, neuron-glia 2 (a transmembrane chondroitin sulfate proteoglycan); CAR, chimeric antigen receptors; Hu, human; KLH, keyhole limpet hemocyanin; Th antigen, Thomsen-nouvelle antigen (GalNAco1-O-Ser/Thr); STn, sialyl-Tn; TF, Thomsen-Friedenreich antigen; Zap, saporin.

administered orally to inhibit GlcCer synthase, delayed tumor development of MEB4 murine cells (146). This could be further explored in human cancer as a therapeutic approach, aiming at intervene on GSL metabolism of tumor cells and modulate GSLs shedding, thus lessening the immunomodulatory effects of GSLs (39).

Glycoengineering is another promising therapeutic approach for cancer (147). Essentially, a spectrum of scientific disciplines, such as carbohydrate chemistry, chemical biology, and glycobiology, converge for creating improved or novel glycan products to control human health and disease (147). For instance, the first globo-H vaccine for clinical use was developed in 2001 (148).
The cell-surface GSL globo-H is a member of a family of tumorassociated antigens highly expressed on several types of cancers. Then, an optimized vaccine against the globo- $\mathrm{H}$ containing five prostate and breast cancer-associated carbohydrate antigens including GM2 was reported (125). More recently, a globo-H vaccine with different carriers and adjuvants was developed to improve the immunogenicity and safety profile (149). Over the last few years, some studies demonstrated an efficient metabolic glycoengineering of GM3 on melanoma cells with monoclonal antibody-mediated selective killing of glycoengineered cancer cells. Basically, cells were metabolically labeled both in vivo and in vitro with $\mathrm{N}$-phenylacetyl-D-mannosamine (ManNPhAc) and 
then selectively targeted and killed with a monoclonal antibody (2H3) recognizing both GM3NPhAc and ManNPhAc $(150,151)$.

\section{CONCLUDING REMARKS}

Cells becoming cancerous develop profound metabolic changes that influence plasma membrane composition. The expression/ overexpression of TACAs antigens such as gangliosides on cancer cell surface are involved in tumor evasion from the immune response. However, cancer therapy can exploit this undesirable expression as targets. Table 1 summarizes some of the current and promising cancer treatments aiming at gangliosides. Monoclonal antibodies clearly represent one of the most important strategies employed (152). Recent studies demonstrated how the levels of antibody-mediated inverse hormesis could differentially influence tumor growth (153). These findings may have important implications for cancer immunotherapy with antibodies, including those against glycolipids. Remarkable glycoengineering advances for the development of new and better anticancer antibodies, along with the design of novel and specific inhibitors

\section{REFERENCES}

1. Crespo PM, Demichelis VT, Daniotti JL. Neobiosynthesis of glycosphingolipids by plasma membrane-associated glycosyltransferases. J Biol Chem (2010) 285(38):29179-90. doi:10.1074/jbc.M110.123422

2. Vilcaes AA, Demichelis VT, Daniotti JL. Trans-activity of plasma membrane-associated ganglioside sialyltransferase in mammalian cells. $J$ Biol Chem (2011) 286(36):31437-46. doi:10.1074/jbc.M111.257196

3. Iwamori M, Iwamori Y. Changes in the glycolipid composition and characteristic activation of GM3 synthase in the thymus of mouse after administration of dexamethasone. Glycoconj J (2005) 22(3):119-26. doi:10.1007/ s10719-005-0363-9

4. Yogeeswaran G, Laine RA, Hakomori S. Mechanism of cell contact-dependent glycolipid synthesis: further studies with glycolipid-glass complex. Biochem Biophys Res Commun (1974) 59(2):591-9. doi:10.1016/ S0006-291X(74)80021-5

5. Daniotti JL, Iglesias-Bartolome R. Metabolic pathways and intracellular trafficking of gangliosides. IUBMB Life (2011) 63(7):513-20. doi:10.1002/ iub. 477

6. Hanada K, Kumagai K, Yasuda S, Miura Y, Kawano M, Fukasawa M, et al. Molecular machinery for non-vesicular trafficking of ceramide. Nature (2003) 426(6968):803-9. doi:10.1038/nature02188

7. Maccioni HJ, Quiroga R, Ferrari ML. Cellular and molecular biology of glycosphingolipid glycosylation. J Neurochem (2011) 117(4):589-602. doi:10.1111/j.1471-4159.2011.07232.x

8. Merrill AH Jr. Sphingolipid and glycosphingolipid metabolic pathways in the era of sphingolipidomics. Chem Rev (2011) 111(10):6387-422. doi:10.1021/ cr2002917

9. Tettamanti G. Ganglioside/glycosphingolipid turnover: new concepts. Glycoconj J (2004) 20(5):301-17. doi:10.1023/B:GLYC.0000033627.02765.cc

10. Mencarelli S, Cavalieri C, Magini A, Tancini B, Basso L, Lemansky P, et al. Identification of plasma membrane associated mature beta-hexosaminidase A, active towards GM2 ganglioside, in human fibroblasts. FEBS Lett (2005) 579(25):5501-6. doi:10.1016/j.febslet.2005.08.081

11. Miyagi T, Yamaguchi K. Mammalian sialidases: physiological and pathological roles in cellular functions. Glycobiology (2012) 22(7):880-96. doi:10.1093/ glycob/cws057

12. Prinetti A, Chigorno V, Mauri L, Loberto N, Sonnino S. Modulation of cell functions by glycosphingolipid metabolic remodeling in the plasma membrane. JNeurochem (2007) 103:113-25.doi:10.1111/j.1471-4159.2007.04714.x of glycolipid synthesis or the precise delivery of cytotoxic agents, are renewing the applicability of gangliosides as targets for cancer therapy.

\section{AUTHOR CONTRIBUTIONS}

JD, RL, and AV contributed to the conception and design of the work. All authors wrote, edited, and reviewed the final manuscript version.

\section{ACKNOWLEDGMENTS}

This work was supported in part by Grants from Secretaría de Ciencia y Tecnología (SECyT, 05/C662), Universidad Nacional de Córdoba (UNC), Consejo Nacional de Investigaciones Científicas y Técnicas (CONICET, PIP 112-20110100930), and Agencia Nacional de Promoción Científica y Tecnológica (ANPCyT, PICT-2013-0456), Argentina. JD and AV are career investigators of CONICET (Argentina). We apologize to all colleagues whose relevant work could not be cited here because of space limitations.

13. Rodriguez-Walker M, Vilcaes AA, Garbarino-Pico E, Daniotti JL. Role of plasma-membrane-bound sialidase NEU3 in clathrin-mediated endocytosis. Biochem J (2015) 470(1):131-44. doi:10.1042/BJ20141550

14. Sonnino S, Aureli M, Loberto N, Chigorno V, Prinetti A. Fine tuning of cell functions through remodeling of glycosphingolipids by plasma membrane-associated glycohydrolases. FEBS Lett (2010) 584(9):1914-22. doi:10.1016/j.febslet.2009.11.020

15. Kolter T. Ganglioside biochemistry. ISRN Biochem (2012) 2012:506160. doi:10.5402/2012/506160

16. Kolter T, Sandhoff K. Lysosomal degradation of membrane lipids. FEBS Lett (2010) 584(9):1700-12. doi:10.1016/j.febslet.2009.10.021

17. Sandhoff K, Kolter T. Biosynthesis and degradation of mammalian glycosphingolipids. Philos Trans R Soc Lond B Biol Sci (2003) 358(1433):847-61. doi:10.1098/rstb.2003.1265

18. Daniotti JL, Vilcaes AA, Torres Demichelis V, Ruggiero FM, RodriguezWalker M. Glycosylation of glycolipids in cancer: basis for development of novel therapeutic approaches. Front Oncol (2013) 3:306. doi:10.3389/ fonc. 2013.00306

19. Hakomori S. Glycosphingolipids in cellular interaction, differentiation, and oncogenesis. Annu Rev Biochem (1981) 50:733-64. doi:10.1146/annurev. bi.50.070181.003505

20. Maccioni HJ. Glycosylation of glycolipids in the Golgi complex. J Neurochem (2007) 103:81-90. doi:10.1111/j.1471-4159.2007.04717.x

21. Maccioni HJ, Daniotti JL, Martina JA. Organization of ganglioside synthesis in the Golgi apparatus. Biochim Biophys Acta (1999) 1437(2):101-18. doi:10.1016/S1388-1981(99)00002-5

22. Daniotti JL, Crespo PM, Yamashita T. In vivo modulation of epidermal growth factor receptor phosphorylation in mice expressing different gangliosides. J Cell Biochem (2006) 99(5):1442-51. doi:10.1002/ jcb. 21034

23. Lopez PH, Schnaar RL. Gangliosides in cell recognition and membrane protein regulation. Curr Opin Struct Biol (2009) 19(5):549-57. doi:10.1016/j. sbi.2009.06.001

24. Proia RL. Glycosphingolipid functions: insights from engineered mouse models. Philos Trans R Soc Lond B Biol Sci (2003) 358(1433):879-83. doi:10.1098/rstb.2003.1268

25. Regina Todeschini A, Hakomori SI. Functional role of glycosphingolipids and gangliosides in control of cell adhesion, motility, and growth, through glycosynaptic microdomains. Biochim Biophys Acta (2008) 1780(3):421-33. doi:10.1016/j.bbagen.2007.10.008 
26. Yamashita T, Hashiramoto A, Haluzik M, Mizukami H, Beck S, Norton A, et al. Enhanced insulin sensitivity in mice lacking ganglioside GM3. Proc Natl Acad Sci U S A (2003) 100(6):3445-9. doi:10.1073/ pnas. 0635898100

27. Ziulkoski AL, Andrade CM, Crespo PM, Sisti E, Trindade VM, Daniotti JL, et al. Gangliosides of myelosupportive stroma cells are transferred to myeloid progenitors and are required for their survival and proliferation. Biochem $J$ (2006) 394(Pt 1):1-9. doi:10.1042/BJ20051189

28. Zurita AR, Maccioni HJ, Daniotti JL. Modulation of epidermal growth factor receptor phosphorylation by endogenously expressed gangliosides. Biochem $J$ (2001) 355(Pt 2):465-72. doi:10.1042/0264-6021:3550465

29. d'Azzo A, Bonten E. Molecular mechanisms of pathogenesis in a glycosphingolipid and a glycoprotein storage disease. Biochem Soc Trans (2010) 38(6):1453-7. doi:10.1042/BST0381453

30. Kolter T, Sandhoff K. Sphingolipid metabolism diseases. Biochim Biophys Acta (2006) 1758(12):2057-79. doi:10.1016/j.bbamem.2006.05.027

31. Platt FM. Sphingolipid lysosomal storage disorders. Nature (2014) 510(7503):68-75. doi:10.1038/nature13476

32. Harlalka GV, Lehman A, Chioza B, Baple EL, Maroofian R, Cross H, et al. Mutations in B4GALNT1 (GM2 synthase) underlie a new disorder of ganglioside biosynthesis. Brain (2013) 136(Pt 12):3618-24. doi:10.1093/brain/ awt270

33. Hu H, Eggers K, Chen W, Garshasbi M, Motazacker MM, Wrogemann $\mathrm{K}$, et al. ST3GAL3 mutations impair the development of higher cognitive functions. Am J Hum Genet (2011) 89(3):407-14. doi:10.1016/j. ajhg.2011.08.008

34. Simpson MA, Cross H, Proukakis C, Priestman DA, Neville DC, Reinkensmeier G, et al. Infantile-onset symptomatic epilepsy syndrome caused by a homozygous loss-of-function mutation of GM3 synthase. Nat Genet (2004) 36(11):1225-9. doi:10.1038/ng1460

35. Kloppel TM, Keenan TW, Freeman MJ, Morré DJ. Glycolipid-bound sialic acid in serum: increased levels in mice and humans bearing mammary carcinomas. Proc Natl Acad Sci U S A (1977) 74(7):3011-3. doi:10.1073/ pnas.74.7.3011

36. Lauc G, Heffer-Lauc M. Shedding and uptake of gangliosides and glycosylphosphatidylinositol-anchored proteins. Biochim Biophys Acta (2006) 1760(4):584-602. doi:10.1016/j.bbagen.2005.11.014

37. Olshefski R, Ladisch S. Intercellular transfer of shed tumor cell gangliosides. FEBS Lett (1996) 386(1):11-4. doi:10.1016/0014-5793(96)00392-4

38. Portoukalian J, Zwingelstein G, Abdul-Malak N, Doré JF. Alteration of gangliosides in plasma and red cells of humans bearing melanoma tumors. Biochem Biophys Res Commun (1978) 85(3):916-20. doi:10.1016/0006-291X(78)90630-7

39. Lardone RD, Cely I, Sieling PA, Lee DJ. Immune response modulation by tumor-secreted glycosphingolipids. J Glycobiol (2014) 3(1):107. doi:10.4172/2168-958X.1000107

40. Kim R, Emi M, Tanabe K. Cancer immunoediting from immune surveillance to immune escape. Immunology (2007) 121(1):1-14. doi:10.1111/j.1365-2567.2007.02587.x

41. Boligan KF, Mesa C, Fernandez LE, von Gunten S. Cancer intelligence acquired (CIA): tumor glycosylation and sialylation codes dismantling antitumor defense. Cell Mol Life Sci (2015) 72(7):1231-48. doi:10.1007/ s00018-014-1799-5

42. Andreesen R, Osterholz J, Bross KJ, Schulz A, Luckenbach GA, Löhr GW. Cytotoxic effector cell function at different stages of human monocyte-macrophage maturation. Cancer Res (1983) 43(12 Pt 1):5931-6.

43. Lefebvre ML, Krause SW, Salcedo M, Nardin A. Ex vivo-activated human macrophages kill chronic lymphocytic leukemia cells in the presence of rituximab: mechanism of antibody-dependent cellular cytotoxicity and impact of human serum. J Immunother (2006) 29(4):388-97. doi:10.1097/01. cji.0000203081.43235.d7

44. Hume DA. Macrophages as APC and the dendritic cell myth. J Immunol (2008) 181(9):5829-35. doi:10.4049/jimmunol.181.9.5829

45. Zamai L, Ponti C, Mirandola P, Gobbi G, Papa S, Galeotti L, et al. NK cells and cancer. J Immunol (2007) 178(7):4011-6. doi:10.4049/ jimmunol.178.7.4011

46. Porcelli SA, Modlin RL. The CD1 system: antigen-presenting molecules for T cell recognition of lipids and glycolipids. Annu Rev Immunol (1999) 17(1):297-329. doi:10.1146/annurev.immunol.17.1.297
47. Lee AF, Sieling PA, Lee DJ. Immune correlates of melanoma survival in adoptive cell therapy. Oncoimmunology (2013) 2(2):e22889. doi:10.4161/ onci.22889

48. Heitger A, Ladisch S. Gangliosides block antigen presentation by human monocytes. Biochim Biophys Acta (1996) 1303(2):161-8. doi:10.1016/0005-2760(96)00091-4

49. Caldwell S, Heitger A, Shen W, Liu Y, Taylor B, Ladisch S. Mechanisms of ganglioside inhibition of APC function. J Immunol (2003) 171(4):1676-83. doi:10.4049/jimmunol.171.4.1676

50. Ziegler-Heitbrock HW, Käfferlein E, Haas JG, Meyer N, Ströbel M, Weber C, et al. Gangliosides suppress tumor necrosis factor production in human monocytes. J Immunol (1992) 148(6):1753-8.

51. Hoon DS, Jung T, Naungayan J, Cochran AJ, Morton DL, McBride WH. Modulation of human macrophage functions by gangliosides. Immunol Lett (1989) 20(4):269-75. doi:10.1016/0165-2478(89)90034-5

52. Shen W, Stone K, Jales A, Leitenberg D, Ladisch S. Inhibition of TLR activation and up-regulation of IL-1R-associated kinase-M expression by exogenous gangliosides. JImmunol (2008) 180(7):4425-32. doi:10.4049/ jimmunol.180.7.4425

53. Kim SJ, Chung TW, Choi HJ, Jin UH, Ha KT, Lee YC, et al. Monosialic ganglioside GM3 specifically suppresses the monocyte adhesion to endothelial cells for inflammation. Int J Biochem Cell Biol (2014) 46:32-8. doi:10.1016/j. biocel.2013.09.015

54. Wondimu A, Liu Y, Su Y, Bobb D, Ma JS, Chakrabarti L, et al. Gangliosides drive the tumor infiltration and function of myeloid-derived suppressor cells. Cancer Res (2014) 74(19):5449-57. doi:10.1158/0008-5472.CAN-14-0927

55. Wölfl M, Batten WY, Posovszky C, Bernhard H, Berthold F. Gangliosides inhibit the development from monocytes to dendritic cells. Clin Exp Immunol (2002) 130(3):441-8. doi:10.1046/j.1365-2249.2002.02006.x

56. Shen W, Falahati R, Stark R, Leitenberg D, Ladisch S. Modulation of CD4 Th cell differentiation by ganglioside GD1a in vitro. JImmunol (2005) 175(8):4927-34. doi:10.4049/jimmunol.175.8.4927

57. Péguet-Navarro J, Sportouch M, Popa I, Berthier O, Schmitt D, Portoukalian J. Gangliosides from human melanoma tumors impair dendritic cell differentiation from monocytes and induce their apoptosis. JImmunol (2003) 170(7):3488-94. doi:10.4049/jimmunol.170.7.3488

58. Bennaceur K, Popa I, Chapman JA, Migdal C, Péguet-Navarro J, Touraine JL, et al. Different mechanisms are involved in apoptosis induced by melanoma gangliosides on human monocyte-derived dendritic cells. Glycobiology (2009) 19(6):576-82. doi:10.1093/glycob/cwp015

59. Bennaceur K, Popa I, Portoukalian J, Berthier-Vergnes O, Péguet-Navarro J. Melanoma-derived gangliosides impair migratory and antigen-presenting function of human epidermal Langerhans cells and induce their apoptosis. Int Immunol (2006) 18(6):879-86. doi:10.1093/intimm/dx1024

60. Jandus C, Boligan KF, Chijioke O, Liu H, Dahlhaus M, Démoulins T, et al. Interactions between Siglec-7/9 receptors and ligands influence NK cell-dependent tumor immunosurveillance. J Clin Invest (2014) 124(4):1810-20. doi:10.1172/JCI65899

61. Kawasaki Y, Ito A, Withers DA, Taima T, Kakoi N, Saito S, et al. Ganglioside DSGb5, preferred ligand for Siglec-7, inhibits NK cell cytotoxicity against renal cell carcinoma cells. Glycobiology (2010) 20(11):1373-9. doi:10.1093/ glycob/cwq116

62. Nicoll G, Avril T, Lock K, Furukawa K, Bovin N, Crocker PR. Ganglioside GD3 expression on target cells can modulate NK cell cytotoxicity via siglec-7-dependent and -independent mechanisms. Eur J Immunol (2003) 33(6):1642-8. doi:10.1002/eji.200323693

63. Webb TJ, Li X, Giuntoli RLII, Lopez PH, Heuser C, Schnaar RL, et al. Molecular identification of GD3 as a suppressor of the innate immune response in ovarian cancer. Cancer Res (2012) 72(15):3744-52. doi:10.1158/0008-5472. CAN-11-2695

64. Sriram V, Cho S, Li P, O’Donnell PW, Dunn C, Hayakawa K, et al. Inhibition of glycolipid shedding rescues recognition of a CD1+ T cell lymphoma by natural killer T (NKT) cells. Proc Natl Acad Sci U S A (2002) 99(12):8197-202. doi:10.1073/pnas.122636199

65. Kimata H, Yoshida A. Differential effects of gangliosides on Ig production and proliferation by human B cells. Blood (1994) 84(4):1193-200.

66. Kimata $\mathrm{H}$, Yoshida A. Inhibition of spontaneous immunoglobulin production by ganglioside GM2 in human B cells. Clin Immunol Immunopathol (1996) 79(2):197-202. doi:10.1006/clin.1996.0068 
67. Kanda N, Tamaki K. Ganglioside GD1b suppresses immunoglobulin production by human peripheral blood mononuclear cells. Exp Hematol (1999) 27(10):1487-93. doi:10.1016/S0301-472X(99)00093-4

68. Kanda N, Tamaki K. Ganglioside GT1b suppresses immunoglobulin production by human peripheral blood mononuclear cells. Immunology (1999) 96(4):628-33. doi:10.1046/j.1365-2567.1999.00734.x

69. Kanda N, Tamaki K. Ganglioside GQ1b enhances Ig production by human PBMCs. J Allergy Clin Immunol (1998) 102(5):813-20. doi:10.1016/ S0091-6749(98)70022-3

70. Kanda N, Watanabe S. Ganglioside GD1a enhances immunoglobulin production by human peripheral blood mononuclear cells. Exp Hematol (2000) 28(6):672-9. doi:10.1016/S0301-472X(00)00167-3

71. Zhou J, Shao H, Cox NR, Baker HJ, Ewald SJ. Gangliosides enhance apoptosis of thymocytes. Cell Immunol (1998) 183(2):90-8. doi:10.1006/ cimm. 1998.1247

72. Inokuchi J, Nagafuku M, Ohno I, Suzuki A. Distinct selectivity of gangliosides required for CD4(+) T and CD8(+) T cell activation. Biochim Biophys Acta (2015) 1851(1):98-106. doi:10.1016/j.bbalip.2014.07.013

73. Nakamori M, Iwahashi M, Nakamura M, Ueda K, Zhang X, Yamaue H. Intensification of antitumor effect by $\mathrm{T}$ helper 1-dominant adoptive immunogene therapy for advanced orthotopic colon cancer. Clin Cancer Res (2003) 9(6):2357-65.

74. Sharma S, Stolina M, Lin Y, Gardner B, Miller PW, Kronenberg M, et al. T cell-derived IL-10 promotes lung cancer growth by suppressing both $\mathrm{T}$ cell and APC function. J Immunol (1999) 163(9):5020-8.

75. Pellegrini P, Berghella AM, Del Beato T, Cicia S, Adorno D, Casciani CU. Disregulation in TH1 and TH2 subsets of CD4+ T cells in peripheral blood of colorectal cancer patients and involvement in cancer establishment and progression. Cancer Immunol Immunother (1996) 42(1):1-8. doi:10.1007/ s002620050244

76. Baeuerle PA, Henkel T. Function and activation of NF-kappa B in the immune system. Annu Rev Immunol (1994) 12(1):141-79. doi:10.1146/ annurev.iy.12.040194.001041

77. Uzzo RG, Rayman P, Kolenko V, Clark PE, Cathcart MK, Bloom T, et al. Renal cell carcinoma-derived gangliosides suppress nuclear factor-kappaB activation in T cells. J Clin Invest (1999) 104(6):769-76. doi:10.1172/ JCI6775

78. Thornton MV, Kudo D, Rayman P, Horton C, Molto L, Cathcart MK, et al. Degradation of NF- $\mathrm{KB}$ in T cells by gangliosides expressed on renal cell carcinomas. J Immunol (2004) 172(6):3480-90. doi:10.4049/jimmunol.172.6.3480

79. Crespo FA, Sun X, Cripps JG, Fernandez-Botran R. The immunoregulatory effects of gangliosides involve immune deviation favoring type- $2 \mathrm{~T}$ cell responses. J Leukoc Biol (2006) 79(3):586-95. doi:10.1189/jlb.0705395

80. Rayman P, Wesa AK, Richmond AL, Das T, Biswas K, Raval G, et al. Effect of renal cell carcinomas on the development of type $1 \mathrm{~T}$-cell responses. Clin Cancer Res (2004) 10(18 Pt 2):6360S-6S. doi:10.1158/1078-0432. CCR-050011

81. Irani DN, Lin KI, Griffin DE. Brain-derived gangliosides regulate the cytokine production and proliferation of activated T cells. J Immunol (1996) 157(10):4333-40.

82. Biswas S, Biswas K, Richmond A, Ko J, Ghosh S, Simmons M, et al. Elevated levels of select gangliosides in T cells from renal cell carcinoma patients is associated with T cell dysfunction. JImmunol (2009) 183(8):5050-8. doi:10.4049/jimmunol.0900259

83. Kudo D, Rayman P, Horton C, Cathcart MK, Bukowski RM, Thornton M, et al. Gangliosides expressed by the renal cell carcinoma cell line SK-RC45 are involved in tumor-induced apoptosis of T cells. Cancer Res (2003) 63(7):1676-83.

84. Sa G, Das T, Moon C, Hilston CM, Rayman PA, Rini BI, et al. GD3, an overexpressed tumor-derived ganglioside, mediates the apoptosis of activated but not resting T cells. Cancer Res (2009) 69(7):3095-104. doi:10.1158/00085472.CAN-08-3776

85. Mahata B, Biswas S, Rayman P, Chahlavi A, Ko J, Bhattacharjee A, et al. GBM derived gangliosides induce $\mathrm{T}$ cell apoptosis through activation of the caspase cascade involving both the extrinsic and the intrinsic pathway. PLoS One (2015) 10(7):e0134425. doi:10.1371/journal.pone.0134425

86. Raval G, Biswas S, Rayman P, Biswas K, Sa G, Ghosh S, et al. TNF-alpha induction of GM2 expression on renal cell carcinomas promotes $\mathrm{T}$ cell dysfunction. J Immunol (2007) 178(10):6642-52. doi:10.4049/jimmunol.178.10.6642
87. Chu JW, Sharom FJ. Gangliosides inhibit T-lymphocyte proliferation by preventing the interaction of interleukin-2 with its cell surface receptors. Immunology (1993) 79(1):10-7.

88. McKallip R, Li R, Ladisch S. Tumor gangliosides inhibit the tumor-specific immune response. J Immunol (1999) 163(7):3718-26.

89. Lee HC, Wondimu A, Liu Y, Ma JS, Radoja S, Ladisch S. Ganglioside inhibition of $\mathrm{CD} 8+\mathrm{T}$ cell cytotoxicity: interference with lytic granule trafficking and exocytosis. J Immunol (2012) 189(7):3521-7. doi:10.4049/ jimmunol.1201256

90. Lo AS, Ma Q, Liu DL, Junghans RP. Anti-GD3 chimeric sFv-CD28/T-cell receptor zeta designer $\mathrm{T}$ cells for treatment of metastatic melanoma and other neuroectodermal tumors. Clin Cancer Res (2010) 16(10):2769-80. doi:10.1158/1078-0432.CCR-10-0043

91. Morton DL, Barth A. Vaccine therapy for malignant melanoma. CA Cancer J Clin (1996) 46(4):225-44. doi:10.3322/canjclin.46.4.225

92. Nores GA, Dohi T, Taniguchi M, Hakomori S. Density-dependent recognition of cell surface GM3 by a certain anti-melanoma antibody, and GM3 lactone as a possible immunogen: requirements for tumor-associated antigen and immunogen. J Immunol (1987) 139(9):3171-6.

93. Cheresh DA, Rosenberg J, Mujoo K, Hirschowitz L, Reisfeld RA. Biosynthesis and expression of the disialoganglioside GD2, a relevant target antigen on small cell lung carcinoma for monoclonal antibody-mediated cytolysis. Cancer Res (1986) 46(10):5112-8.

94. Zhang S, Cordon-Cardo C, Zhang HS, Reuter VE, Adluri S, Hamilton WB, et al. Selection of tumor antigens as targets for immune attack using immunohistochemistry: I. Focus on gangliosides. Int J Cancer (1997) 73(1):42-9. doi:10.1002/(SICI)1097-0215(19970926)73:1<42::AID-IJC8>3.0.CO;2-1

95. Tangvoranuntakul P, Gagneux P, Diaz S, Bardor M, Varki N, Varki A, et al. Human uptake and incorporation of an immunogenic nonhuman dietary sialic acid. Proc Natl Acad Sci U S A (2003) 100(21):12045-50. doi:10.1073/ pnas. 2131556100

96. Nguyen DH, Tangvoranuntakul P, Varki A. Effects of natural human antibodies against a nonhuman sialic acid that metabolically incorporates into activated and malignant immune cells. J Immunol (2005) 175(1):228-36. doi:10.4049/jimmunol.175.1.228

97. Tokuda N, Zhang Q, Yoshida S, Kusunoki S, Urano T, Furukawa K, et al. Genetic mechanisms for the synthesis of fucosyl GM1 in small cell lung cancer cell lines. Glycobiology (2006) 16(10):916-25. doi:10.1093/glycob/cwl022

98. Horwacik I, Rokita H. Targeting of tumor-associated gangliosides with antibodies affects signaling pathways and leads to cell death including apoptosis. Apoptosis (2015) 20(5):679-88. doi:10.1007/s10495-015-1103-7

99. Hakomori SI, Handa K. GM3 and cancer. Glycoconj J (2015) 32(1-2):1-8. doi:10.1007/s10719-014-9572-4

100. Kieber-Emmons T, Saha S, Pashov A, Monzavi-Karbassi B, Murali R. Carbohydrate-mimetic peptides for pan anti-tumor responses. Front Immunol (2014) 5:308. doi:10.3389/fimmu.2014.00308

101. Ahmed M, Cheung NK. Engineering anti-GD2 monoclonal antibodies for cancer immunotherapy. FEBS Lett (2014) 588(2):288-97. doi:10.1016/j. febslet.2013.11.030

102. Gómez RE, Ardigo ML. Anti-idiotype antibodies in cancer treatment: the pharmaceutical industry perspective. Front Oncol (2012) 2:147. doi:10.3389/ fonc. 2012.00147

103. Nasi ML, Meyers M, Livingston PO, Houghton AN, Chapman PB. Antimelanoma effects of R24, a monoclonal antibody against GD3 ganglioside. Melanoma Res (1997) 7:S155-62. doi:10.1097/00008390-199708001-00024

104. Ravindranath $\mathrm{MH}$, Morton DL. Role of gangliosides in active immunotherapy with melanoma vaccine. Int Rev Immunol (1991) 7(4):303-29. doi:10.3109/08830189109114877

105. Slovin SF, Keding SJ, Ragupathi G. Carbohydrate vaccines as immunotherapy for cancer. Immunol Cell Biol (2005) 83(4):418-28. doi:10.1111/j.1440-1711.2005.01350.x

106. Gilbert ER, Eby JM, Hammer AM, Klarquist J, Christensen DG, Barfuss AJ, et al. Positioning ganglioside D3 as an immunotherapeutic target in lymphangioleiomyomatosis. Am J Pathol (2013) 183(1):226-34. doi:10.1016/j. ajpath.2013.04.002

107. Pukel CS, Lloyd KO, Travassos LR, Dippold WG, Oettgen HF, Old LJ. GD3, a prominent ganglioside of human melanoma. Detection and characterisation by mouse monoclonal antibody. J Exp Med (1982) 155(4):1133-47. doi:10.1084/jem.155.4.1133 
108. Iglesias-Bartolomé R, Crespo PM, Gomez GA, Daniotti JL. The antibody to GD3 ganglioside, R24, is rapidly endocytosed and recycled to the plasma membrane via the endocytic recycling compartment. Inhibitory effect of brefeldin A and monensin. FEBS J (2006) 273(8):1744-58. doi:10.1111/j.1742-4658.2006.05194.x

109. Torres Demichelis V, Vilcaes AA, Iglesias-Bartolomé R, Ruggiero FM, Daniotti JL. Targeted delivery of immunotoxin by antibody to ganglioside GD3: a novel drug delivery route for tumor cells. PLoS One (2013) 8(1):e55304. doi:10.1371/journal.pone.0055304

110. Higgins SC, Fillmore HL, Ashkan K, Butt AM, Pilkington GJ. Dual targeting NG2 and GD3A using Mab-Zap immunotoxin results in reduced glioma cell viability in vitro. Anticancer Res (2015) 35(1):77-84.

111. Guillemard V, Saragovi HU. Taxane-antibody conjugates afford potent cytotoxicity, enhanced solubility, and tumor target selectivity. Cancer Res (2001) 61(2):694-9.

112. Guillemard V, Uri Saragovi H. Prodrug chemotherapeutics bypass p-glycoprotein resistance and kill tumors in vivo with high efficacy and target-dependent selectivity. Oncogene (2004) 23(20):3613-21. doi:10.1038/ sj.onc. 1207463

113. Gajdosik Z. Racotumomab - a novel anti-idiotype monoclonal antibody vaccine for the treatment of cancer. Drugs Today (Barc) (2014) 50(4):301-7. doi:10.1358/dot.2014.50.4.2116670

114. Alfonso S, Valdés-Zayas A, Santiesteban ER, Flores YI, Areces F, Hernández $\mathrm{M}$, et al. A randomized, multicenter, placebo-controlled clinical trial of racotumomab-alum vaccine as switch maintenance therapy in advanced non-small cell lung cancer patients. Clin Cancer Res (2014) 20(14):3660-71. doi:10.1158/1078-0432.CCR-13-1674

115. Yu AL, Gilman AL, Ozkaynak MF, London WB, Kreissman SG, Chen HX, et al. Anti-GD2 antibody with GM-CSF, interleukin-2, and isotretinoin for neuroblastoma. N Engl J Med (2010) 363(14):1324-34. doi:10.1056/ NEJMoa0911123

116. Navid F, Sondel PM, Barfield R, Shulkin BL, Kaufman RA, Allay JA, et al. Phase I trial of a novel anti-GD2 monoclonal antibody, Hu14.18K322A, designed to decrease toxicity in children with refractory or recurrent neuroblastoma. $J$ Clin Oncol (2014) 32(14):1445-52. doi:10.1200/JCO.2013.50.4423

117. Shusterman S, London WB, Gillies SD, Hank JA, Voss SD, Seeger RC, et al. Antitumor activity of hu14.18-IL2 in patients with relapsed/refractory neuroblastoma: a Children's Oncology Group (COG) phase II study. J Clin Oncol (2010) 28(33):4969-75. doi:10.1200/JCO.2009.27.8861

118. Albertini MR, Hank JA, Gadbaw B, Kostlevy J, Haldeman J, Schalch H, et al. Phase II trial of hu14.18-IL2 for patients with metastatic melanoma. Cancer Immunol Immunother (2012) 61(12):2261-71. doi:10.1007/ s00262-012-1286-5

119. Young PA, Morrison SL, Timmerman JM. Antibody-cytokine fusion proteins for treatment of cancer: engineering cytokines for improved efficacy and safety. Semin Oncol (2014) 41(5):623-36. doi:10.1053/j.seminoncol.2014.08.002

120. Esser R, Müller T, Stefes D, Kloess S, Seidel D, Gillies SD, et al. NK cells engineered to express a GD2-specific antigen receptor display built-in ADCC-like activity against tumour cells of neuroectodermal origin. J Cell Mol Med (2012) 16(3):569-81. doi:10.1111/j.1582-4934.2011.01343.x

121. Lode HN, Schmidt M, Seidel D, Huebener N, Brackrock D, Bleeke M, et al. Vaccination with anti-idiotype antibody ganglidiomab mediates a GD(2)specific anti-neuroblastoma immune response. Cancer Immunol Immunother (2013) 62(6):999-1010. doi:10.1007/s00262-013-1413-y

122. Kwon HY, Kim SJ, Kim CH, Son SW, Kim KS, Lee JH, et al. Triptolide downregulates human GD3 synthase (hST8Sia I) gene expression in SK-MEL-2 human melanoma cells. Exp Mol Med (2010) 42(12):849-55. doi:10.3858/ emm.2010.42.12.088

123. Battula VL, Shi Y, Evans KW, Wang RY, Spaeth EL, Jacamo RO, et al. Ganglioside GD2 identifies breast cancer stem cells and promotes tumorigenesis. J Clin Invest (2012) 122(6):2066-78. doi:10.1172/JCI59735

124. Sarkar TR, Battula VL, Werden SJ, Vijay GV, Ramirez-Peña EQ, Taube $\mathrm{JH}$, et al. GD3 synthase regulates epithelial-mesenchymal transition and metastasis in breast cancer. Oncogene (2015) 34(23):2958-67. doi:10.1038/ onc.2014.245

125. Zhu J, Wan Q, Lee D, Yang G, Spassova MK, Ouerfelli O, et al. From synthesis to biologics: preclinical data on a chemistry derived anticancer vaccine. J Am Chem Soc (2009) 131(26):9298-303. doi:10.1021/ja901415s
126. Vázquez AM, Gabri MR, Hernández AM, Alonso DF, Beausoleil I, Gomez $\mathrm{DE}$, et al. Antitumor properties of an anti-idiotypic monoclonal antibody in relation to N-glycolyl-containing gangliosides. Oncol Rep (2000) 7(4):751-6. doi:10.3892/or.7.4.751

127. Alfonso M, Díaz A, Hernández AM, Pérez A, Rodríguez E, Bitton R, et al. An anti-idiotype vaccine elicits a specific response to $\mathrm{N}$-glycolyl sialic acid residues of glycoconjugates in melanoma patients. J Immunol (2002) 168(5):2523-9. doi:10.4049/jimmunol.168.5.2523

128. Vázquez AM, Alfonso M, Lanne B, Karlsson KA, Carr A, Barroso O, et al. Generation ofamurinemonoclonalantibodyspecificforN-glycolylneuraminic acid-containing gangliosides that also recognizes sulfated glycolipids. Hybridoma (1995) 14(6):551-6. doi:10.1089/hyb.1995.14.551

129. van Cruijsen H, Ruiz MG, van der Valk P, de Gruijl TD, Giaccone G. Tissue micro array analysis of ganglioside N-glycolyl GM3 expression and signal transducer and activator of transcription (STAT)-3 activation in relation to dendritic cell infiltration and microvessel density in non-small cell lung cancer. BMC Cancer (2009) 9:180. doi:10.1186/1471-2407-9-180

130. Torbidoni AV, Scursoni A, Camarero S, Segatori V, Gabri M, Alonso D, et al. Immunoreactivity of the $14 \mathrm{~F} 7 \mathrm{Mab}$ raised against $\mathrm{N}$-glycolyl GM3 ganglioside in retinoblastoma tumours. Acta Ophthalmol (2015) 93(4):e294-300. doi:10.1111/aos. 12578

131. Lahera T, Calvo A, Torres G, Rengifo CE, Quintero S, Arango Mdel C, et al. Prognostic role of 14F7 Mabimmunoreactivity against N-glycolyl GM3 ganglioside in colon cancer. J Oncol (2014) 2014:482301. doi:10.1155/2014/482301

132. Cacciavillano W, Sampor C, Venier C, Gabri MR, de Dávila MT, Galluzzo $\mathrm{ML}$, et al. A phase I study of the anti-idiotype vaccine racotumomab in neuroblastoma and other pediatric refractory malignancies. Pediatr Blood Cancer (2015) 62(12):2120-4. doi:10.1002/pbc.25631

133. Hernández AM, Toledo D, Martínez D, Griñán T, Brito V, Macías A, et al. Characterization of the antibody response against NeuGcGM3 ganglioside elicited in non-small cell lung cancer patients immunized with an anti-idiotype antibody. J Immunol (2008) 181(9):6625-34. doi:10.4049/ jimmunol.181.9.6625

134. Vázquez $\mathrm{AM}$, Hernández $\mathrm{AM}$, Macías $\mathrm{A}$, Montero E, Gómez DE, Alonso DF, et al. Racotumomab: an anti-idiotype vaccine related to N-glycolylcontaining gangliosides - preclinical and clinical data. Front Oncol (2012) 2:150. doi:10.3389/fonc. 2012.00150

135. Brändlein S, Pohle T, Ruoff N, Wozniak E, Müller-Hermelink HK, Vollmers HP. Natural IgM antibodies and immunosurveillance mechanisms against epithelial cancer cells in humans. Cancer Res (2003) 63(22):7995-8005.

136. Lacombe J, Mangé A, Jarlier M, Bascoul-Mollevi C, Rouanet P, Lamy PJ, et al. Identification and validation of new autoantibodies for the diagnosis of DCIS and node negative early-stage breast cancers. Int J Cancer (2013) 132(5):1105-13. doi:10.1002/ijc.27766

137. Schneider C, Smith DF, Cummings RD, Boligan KF, Hamilton RG, Bochner BS, et al. The human IgG anti-carbohydrate repertoire exhibits a universal architecture and contains specificity for microbial attachment sites. Sci Transl Med (2015) 7(269):269ral. doi:10.1126/scitranslmed.3010524

138. Rodriguez-Zhurbenko N, Rabade-Chediak M, Martinez D, Griñan T, Hernandez AM. Anti-NeuGcGM3 reactivity: a possible role of natural antibodies and B-1 cells in tumor immunosurveillance. Ann N Y Acad Sci (2015) 1362(1):224-38. doi:10.1111/nyas.12827

139. Rodríguez-Zhurbenko N, Martínez D, Blanco R, Rondón T, Griñán T, Hernández AM. Human antibodies reactive to NeuGcGM3 ganglioside have cytotoxic antitumor properties. Eur J Immunol (2013) 43(3):826-37. doi:10.1002/eji.201242693

140. Cheever MA, Allison JP, Ferris AS, Finn OJ, Hastings BM, Hecht TT, et al. The prioritization of cancer antigens: a national cancer institute pilot project for the acceleration of translational research. Clin Cancer Res (2009) 15(17):5323-37. doi:10.1158/1078-0432.CCR-09-0737

141. Matthay KK, George RE, Yu AL. Promising therapeutic targets in neuroblastoma. Clin Cancer Res (2012) 18(10):2740-53. doi:10.1158/1078-0432. CCR-11-1939

142. Parsons K, Bernhardt B, Strickland B. Targeted immunotherapy for highrisk neuroblastoma - the role of monoclonal antibodies. Ann Pharmacother (2013) 47(2):210-8. doi:10.1345/aph.1R353

143. Pule MA, Savoldo B, Myers GD, Rossig C, Russell HV, Dotti G, et al. Virusspecific $\mathrm{T}$ cells engineered to coexpress tumor-specific receptors: persistence 
and antitumor activity in individuals with neuroblastoma. Nat Med (2008) 14(11):1264-70. doi:10.1038/nm.1882

144. Louis CU, Savoldo B, Dotti G, Pule M, Yvon E, Myers GD, et al. Antitumor activity and long-term fate of chimeric antigen receptor-positive $\mathrm{T}$ cells in patients with neuroblastoma. Blood (2011) 118(23):6050-6. doi:10.1182/ blood-2011-05-354449

145. Liu Y, Wondimu A, Yan S, Bobb D, Ladisch S. Tumor gangliosides accelerate murine tumor angiogenesis. Angiogenesis (2014) 17(3):563-71. doi:10.1007/ s10456-013-9403-4

146. Guerrera M, Ladisch S. N-butyldeoxynojirimycin inhibits murine melanoma cell ganglioside metabolism and delays tumor onset. Cancer Lett (2003) 201(1):31-40. doi:10.1016/S0304-3835(03)00459-2

147. Hudak JE, Bertozzi CR. Glycotherapy: new advances inspire a reemergence of glycans in medicine. Chem Biol (2014) 21(1):16-37. doi:10.1016/j. chembiol.2013.09.010

148. Gilewski T, Ragupathi G, Bhuta S, Williams LJ, Musselli C, Zhang XF, et al. Immunization of metastatic breast cancer patients with a fully synthetic globo H conjugate: a phase I trial. Proc Natl Acad Sci U S A (2001) 98(6):3270-5. doi:10.1073/pnas.051626298

149. Huang YL, Hung JT, Cheung SK, Lee HY, Chu KC, Li ST, et al. Carbohydratebased vaccines with a glycolipid adjuvant for breast cancer. Proc Natl Acad Sci U S A (2013) 110(7):2517-22. doi:10.1073/pnas.1222649110

150. Qiu L, Gong X, Wang Q, Li J, Hu H, Wu Q, et al. Combining synthetic carbohydrate vaccines with cancer cell glycoengineering for effective cancer immunotherapy. Cancer Immunol Immunother (2012) 61(11):2045-54. doi:10.1007/s00262-012-1224-6

151. Wang Q, Zhang J, Guo Z. Efficient glycoengineering of GM3 on melanoma cell and monoclonal antibody-mediated selective killing of the glycoengineered cancer cell. Bioorg Med Chem (2007) 15(24):7561-7. doi:10.1016/j. bmc.2007.09.005

152. Weiner GJ. Building better monoclonal antibody-based therapeutics. Nat Rev Cancer (2015) 15(6):361-70. doi:10.1038/nrc3930

153. Pearce OM, Läubli H, Verhagen A, Secrest P, Zhang J, Varki NM, et al. Inverse hormesis of cancer growth mediated by narrow ranges of tumor-directed antibodies. Proc Natl Acad Sci US A (2014) 111(16):5998-6003. doi:10.1073/ pnas. 1209067111

Conflict of Interest Statement: The authors declare that the research was conducted in the absence of any commercial or financial relationships that could be construed as a potential conflict of interest.

Copyright (c) 2016 Daniotti, Lardone and Vilcaes. This is an open-access article distributed under the terms of the Creative Commons Attribution License (CC BY). The use, distribution or reproduction in other forums is permitted, provided the original author(s) or licensor are credited and that the original publication in this journal is cited, in accordance with accepted academic practice. No use, distribution or reproduction is permitted which does not comply with these terms. 